\title{
The effects of added glycerol or unprotected free fatty acids or a combination of the two on silage intake, milk production, rumen fermentation and diet digestibility in cows given grass silage based diets
}

Hannele Khalili

Agricultural Research Centre of Finland, North-Savo Research Station, FIN-71750 Maaninka, Finland, current address: Agricultural Research Centre of Finland, Animal Production Research, FIN-31600 Jokioinen,

Finland,e-mail: hannele.khalili@mtt.fi

Tuomo Varvikko, Vesa Toivonen

Agricultural Research Centre of Finland, Animal Production Research, FIN-31600 Jokioinen, Finland

Kari Hissa

Finn Feed Ltd, PO Box 105, FIN-00241 Helsinki, Finland

Marjatta Suvitie

Agricultural Research Centre of Finland, North-Savo Research Station, FIN-71750 Maaninka, Finland

\begin{abstract}
The addition of glycerol or free fatty acids either alone or in combination to concentrate was studied for the effects on feed intake, milk production, rumen fermentation, blood metabolites and diet digestibility in dairy cows given grass silage ad libitum. The study was conducted on 12 mid-lactating cows, four of them ruminally cannulated. Barley-based concentrate (control diet, C) was given $7 \mathrm{~kg} / \mathrm{d}$ as fed. In the other three diets, $36 \mathrm{~g} / \mathrm{kg}$ of barley was replaced by glycerol $(\mathrm{G})$ or a mixture of free fatty acids (FA) or by a combination of the two, making a total of $72 \mathrm{~g} / \mathrm{kg}$ (GFA). The experimental design consisted of balanced $4 \times 4$ Latin squares with a $2 \times 2$ factorial arrangement of diets: the effects of G, FA and G*FA interaction. The FA diets significantly decreased silage intake, increased milk yield, decreased milk protein content, increased the concentrations of $\mathrm{C}_{18: 0}, \mathrm{C}_{18: 1}$, and $\mathrm{C}_{20: 1}$ and decreased those of $\mathrm{C}_{8-16}$, and $\mathrm{C}_{18: 3}$ fatty acids in milk fat. The FA diets also increased the concentration of nonesterified fatty acids in plasma, and decreased the digestibility of organic matter and neutral detergent fibre but increased that of fat. Glycerol decreased the molar proportion of acetate and increased the molar proportions of propionate and butyrate in the rumen, but the addition of glycerol did not have any effect on silage intake, milk yield or milk composition. Milk yield was highest when glycerol and free fatty acids were given together, showing a positive interaction.
\end{abstract}

Key words: blood metabolites, digestibility, fatty acids, glycerol, grass silage milk production, rumen fermentation 


\section{AGRICULTURAL AND FOOD SCIENCE IN FINLAND}

Khalili, H. et al. Glycerol and unprotected free fatty acids in the diets of dairy cows

\section{Introduction}

In Finland dairy cows are typically fed grass silage with barley based supplement. Due to the fermentation type in the rumen however, this diet is not optimal if the aim is to decrease the fat content in milk without simultaneous decreasing the milk protein content (Huhtanen 1988, Jaakkola and Huhtanen 1993). Grass silage with barley produces generally a rumen fermentation pattern relatively high in butyrate and low in propionate, which explains the high milk fat content. In addition, glucose supply may be limited in dairy cows, and glucogenic amino acids may then be used for glucose production. As a result, smaller amounts of amino acids will be available for milk protein synthesis. Therefore, grass silage-based diets should be supplemented with a concentrate mixture producing more propionate and less butyrate in the rumen in order to increase the glucose supply to the host animal.

Energy-yielding components other than carbohydrates or their by-products are alternative sources of ingredients that could be included in the concentrate mixture. We look here at the effects of glycerol and unprotected long-chain free fatty acids as dietary supplements. The use of glycerol and fatty acids separately in concentrate mixtures has commercial interest, for instance if these ingredients affect milk yield and composition. In reported trials glycerol has been fermented under different conditions and therefore the proportions of the end products of rumen fermentation have also varied. Information is lacking on the effects of glycerol supplementation on the performance of dairy cows fed grass silage-based diets. Glycerol in the diet could have the potential to increase the glucose supply if the proportion of propionic acid is mainly increased at the expense of other acids. Glucose carbon can be supplied by propionate or any oddcarbon compounds or by glucogenic amino acids (Bergman and Pell 1985). Carbon sources other than propionate include glycerol from mobilized lipids (Van Soest 1994). The addition of fat to the diet is one way of increasing energy intake in order to obtain a higher milk yield provided that feed intake and/or digestibility are not much reduced. The level of supplemental fat is important since high levels cause negative effects but even moderate levels have often been reported to reduce milk protein content (Thomas and Chamberlain 1984, Tesfa et al. 1991a). Jenkins (1993) and Doreau and Ferlay (1995) recently showed that unprotected long-chain fatty acids in the diet interfere with the microbial ecosystem. Dietary fat also affects the milk fatty acid composition, e.g. by reducing the content of short- and medium-chain fatty acids and increasing that of long-chain fatty acids (Palmquist and Jenkins 1980, Coppock and Wilks 1991, Tesfa et al. 1991b). Because, however, dietary fat is modified within the rumen, the profile of longchain fatty acids in milk may not be like that provided in the diet.

Our objective was to study the effects of a low level of free fatty acids because high, and even moderate, levels have negative effects and also because information on the responses of a low level of fatty acids is scarce in grass silagebased diets. We studied the effects of including either glycerol or a mixture of unprotected free fatty acids, mainly $\mathrm{C}_{18: 1}$ and $\mathrm{C}_{18: 2}$, or a combination of glycerol and fatty acids on feed intake, milk production and composition, rumen fermentation, blood metabolites and diet digestibility in dairy cows fed grass silage and a concentrate mixture.

\section{Material and methods}

\section{Animals, diets, and experimental design}

The study was conducted on 12 mid-lactating (115 \pm 31 days in milk) Friesian cows, of which four were cannulated in the rumen, in their first lactation period. The cows were individually fed and milked twice a day, at 0700 and 1600 . A total of $7 \mathrm{~kg}$ of barley-based concentrate (control diet, C) was given twice a day (0800 and 1730) 


\section{AGRICULTURAL AND FOOD SCIENCE IN FINLAND}

Vol. 6 (1997): 349-362.

in two equal meals of $3.5 \mathrm{~kg}$ each. The concentrate (C diets) consisted $(\mathrm{g} / \mathrm{kg})$ of barley $(600)$, oats (80), sugar beet pulp (150), soya-bean meal (95), molasses (20) and others (55). In other three diets, $36 \mathrm{~g} / \mathrm{kg}$ of barley was replaced by glycerol ( $\mathrm{G}$ diets) and a mixture of free fatty acids (FA diets) either alone or in combination (GFA) (36 $\mathrm{g} / \mathrm{kg}$ of glycerol and $36 \mathrm{~g} / \mathrm{kg}$ of fatty acids), making a total of $72 \mathrm{~g} / \mathrm{kg}$. The fatty acid composition $(\mathrm{g} / \mathrm{kg})$ of the mixture of free FA (fractioned vegetable fatty acid blend) was $\mathrm{C}_{16: 0}(126), \mathrm{C}_{18: 0}$ (22), $C_{18: 1}$ (376), $C_{18: 2}$ (274), $C_{18: 3}$ (32) and the rest was a mixture of fatty acids in triglycerides form (170). Wilted grass silage was fed ad libitum, and refusals were between 50 to $100 \mathrm{~g} / \mathrm{kg}$ of the amount offered. Second cut silage was made from a mixture of timothy and meadow fescue, and ensiled with a formic acid based additive (5 1/1000 kg; $690 \mathrm{~g} / \mathrm{kg}$ formic acid). The experiment was carried out as three balanced 4 x 4 Latin squares, each having 21 day periods comprising 14 days for adjustment and 7 days for data collection.

\section{Measurements and analytical procedures}

Milk yield and silage intake were recorded daily. The results presented are based on the data on intake and milk production during the last 6 days of each experimental period. The silage dry matter (DM) content was determined by oven drying at $105^{\circ} \mathrm{C}$ for $24 \mathrm{~h}$, and the DM content was corrected for the volatile losses according to Huida et al. (1986). Feed samples were collected on days 15-19 and pooled within the period. Feed samples were analysed for organic matter (OM), nitrogen $(\mathrm{N})$, neutral detergent fibre (NDF) and $\mathrm{HCl}$ fat. The silage samples were also analysed for $\mathrm{pH}$, water-soluble carbohydrates, lactic acid, ammonia $\mathrm{N}$ and soluble $\mathrm{N}$. Diet digestibility was measured using acid insoluble ash as an internal marker (Van Keulen and Young 1977). During 5 days of each collection period clean (not mixed with urine) faecal grab samples were taken from the four cannulated cows at 0700 and 1900 , and pooled within each cow and frozen. The pooled samples were subsequently thawed and dried at $60^{\circ} \mathrm{C}$ and stored at room temperature for chemical analyses. Samples from the feeds and faeces were analysed for organic matter by ashing at $600^{\circ} \mathrm{C}$ for $12 \mathrm{~h}$, nitrogen (Kjeldahl-N), NDF, ADF and lignin (Robertson and van Soest 1981). $\mathrm{HCl}$ fat was extracted with diethyl ether (AOAC 1990) after boiling for $1 \mathrm{~h}$ in $3 \mathrm{~N} \mathrm{HCl}$. Milk samples were taken during four consecutive milkings on days 17 and 18 and analysed for fat, protein and lactose. Milk samples were pooled within diet for analyses. The composition and amount of milk fatty acids were measured after methylation (Anttila and Kankare 1983) using a Hewlett Packard (Böblingen, Germany) HP 5890 gas chromatograph on a $2 \mathrm{~mm} \times 3 \mathrm{~m}$ glass column packed with GP $10 \%$ SP-2330 on 100/120 Cromosorb WAW (Supelco, Bellofonte USA) and equipped with an HP 7673 automatic injector and flame ionization detector. The column temperature was initially $90^{\circ} \mathrm{C}$ and then programmed to $220^{\circ} \mathrm{C}$ at $8^{\circ} \mathrm{C} / \mathrm{min}$. The split/slitless injector was used in splitless mode at $250^{\circ} \mathrm{C}$ and the detector also at $250^{\circ} \mathrm{C}$. The carrier gas was helium at a flow rate of $40 \mathrm{ml} / \mathrm{min}$. The fatty acid methyl esters were identified and quantitated utlizing the Nu-Check-Prep GLC-60 milk fat standard (Bast of Copenhagen, Denmark) and HP 3365 Chemstation. Blood samples were collected on day 18 before morning feeding and 3 and $6 \mathrm{~h}$ later from the coccygeal vein of each cow into $10 \mathrm{ml}$ EDTA tubes and placed in ice. Beta-hydroxybutyrate (BHB) was analysed from acid precipitated blood according to the method described by Työppönen and Kauppinen (1980). Plasma was separated by centrifugation and samples were analysed enzymatically using commercial kits for glucose (Boehringer Mannheim GmbH, Germany) and for non-esterified fatty acids (NEFA) (Wako Chemicals GmbH, Neuss, Germany; Shimizu et al. 1980). Plasma urea was analysed as described by Gutmann and Bergmeyer (1974). Rumen fluid samples were collected from the four cannulated cows on day 19 before morning feeding and 1.5, 3, 4.5, 6, 7.5 and $9 \mathrm{~h}$ thereafter. $\mathrm{pH}$ was measured immediately. Rumen fluid 


\section{AGRICULTURAL AND FOOD SCIENCE IN FINLAND}

Khalili, H. et al. Glycerol and unprotected free fatty acids in the diets of dairy cows

samples were first strained through cheese cloth, and then $0.5 \mathrm{ml}$ of saturated mercury(II)chloride and $2 \mathrm{ml}$ of $1 \mathrm{M}$ sodium hydroxide were added to $5 \mathrm{ml}$ of rumen fluid. The samples were kept frozen until analysed. Before analysis a $0.5 \mathrm{ml}$ sample was acidified with $0.25 \mathrm{ml}$ of formic acid (Riedel-de-Haen 33015), diluted to $5 \mathrm{ml}$ with distilled water and centrifuged at $2000 \mathrm{~g}$ for $10 \mathrm{~min}$. The VFA content was measured by an HP 5890 gas chromatograph (Hewlett Packard, Avondale, USA) provided with an HP 7673 autosampler, a flame ionization detector and an HP 3365 Chemstation. The capillary column was an HP-FFAP $10 \mathrm{~m} \times 0.53 \mathrm{~mm} \times 1 \mu \mathrm{m}$ (HP, USA). The sample volume injected was $1 \mu \mathrm{l}$. Helium was used as a carrier gas at a flow rate of $9 \mathrm{ml} / \mathrm{min}$. The column temperature was programmed to rise from 60 to $78^{\circ} \mathrm{C}$ at a rate of $25^{\circ} \mathrm{C} / \mathrm{min}$, isothermally at a rate of $7.5^{\circ} \mathrm{C} / \mathrm{min}$ to $100^{\circ} \mathrm{C}$ for $1 \mathrm{~min}$ and finally at a rate of $25^{\circ} \mathrm{C} / \mathrm{min}$ to $180^{\circ} \mathrm{C}$ in the final time of $3 \mathrm{~min}$. The injector was operated in the split mode (split vent flow $45 \mathrm{ml} / \mathrm{min}$ ). The injector and detector temperatures were 220 and $260^{\circ} \mathrm{C}$, respectively. The results were calculated by an external standard method. Ammonia $\mathrm{N}$ was analysed as described by McCullough (1967). The number of protozoa of pooled daily (within each cow) rumen samples were counted, after mixing with methyl green-formalin-saline solution, using a haemo-cytometer. The cows were weighed on two consecutive days at the beginning of the experiment and on two days at the end of each period.

\section{Statistical methods}

Data were analysed by ANOVA for a balanced Latin square design. The model was a mixed one:

$$
\begin{aligned}
\mathrm{y}_{\mathrm{ijkm}}= & \mu+\mathrm{A}_{\mathrm{i}}+\mathrm{P}_{\mathrm{j}}+\mathrm{FA}_{\mathrm{k}}+\mathrm{G}_{\mathrm{l}}+\mathrm{FA}^{*} \mathrm{G}_{\mathrm{kl}}+\mathrm{f}_{\mathrm{ijkl}}+\mathrm{T}_{\mathrm{m}}+ \\
& \mathrm{A}^{*} \mathrm{~T}_{\mathrm{im}}+\mathrm{P} * \mathrm{~T}_{\mathrm{jm}}+\mathrm{FA} \mathrm{T}_{\mathrm{km}}+\mathrm{G}^{*} \mathrm{~T}_{\mathrm{lm}}+ \\
& \mathrm{FA} * \mathrm{G}^{*} \mathrm{~T}_{\mathrm{klm}}+\mathrm{e}_{\mathrm{ijklm}},
\end{aligned}
$$

where $\mu$ is the overall mean, $\mathrm{A}$ and $\mathrm{P}$ are the random effects of animal and period, FA, G and FA* $G$ are the fixed effects of diets, $f_{i j l k}$ is the random error term for whole-plot (mean square of the whole-plot), $\mathrm{T}$ is fixed effect time, $\mathrm{A}^{*} \mathrm{~T}$ and $\mathrm{P} * \mathrm{~T}$ are the random effects of animal*time and period*time, G*T, FA*T and $\mathrm{G}^{*} \mathrm{FA}^{*} \mathrm{~T}$ are the fixed effects of diets*time, and $\mathrm{e}_{\mathrm{ijklm}}$ is the random error term for sub-plot (mean square of the sub-plot). The random variables, $A_{i}, P_{j}, f_{i j k l}$, $\mathrm{A}^{*} \mathrm{~T}_{\mathrm{im}}, \mathrm{P}^{*} \mathrm{~T}_{\mathrm{jm}}$ and $\mathrm{e}_{\mathrm{ijklm}}$, are all assumed to be independent and normally distributed with zero means and variances $\sigma^{2}{ }_{\mathrm{A}}, \sigma_{\mathrm{P}}^{2}, \sigma_{\mathrm{f}}^{2}, \sigma_{\mathrm{AT}}^{2}, \sigma_{\mathrm{PT}}^{2}$ and $\sigma^{2}{ }_{e}$, respectively. The effects of FA, G and $\mathrm{FA}^{*} \mathrm{G}$ on intake, milk production and composition, live weight, mean values of blood metabolites, and mean values of rumen characteristics and digestibility were tested using the whole-plot error mean square as an error variance in the $\mathrm{F}$ test. The effects of FA*time, G*time and $\mathrm{FA} * \mathrm{G} *$ time on the post-prandial values of blood metabolites and rumen characteristics were tested using the sub-plot error mean square as an error variance in the $\mathrm{F}$ test. Statistical significance of treatments was tested $2 \times 2$ factorially: the effect of glycerol ( $\mathrm{G}$ and $\mathrm{G}^{*} \mathrm{FA} v \mathrm{C}$ and FA); the effect of free fatty acids (FA and G*FA $v$ C and $G$ ) and their respective interaction effect G*FA (C and G*FA $v$ G and FA). Blood metabolites and rumen fluid $(\mathrm{pH}$, ammonia, VFA) data were assessed by analysis of variance for repeated measurements. The analysis used the splitplot approach with Greenhouse-Geiser approximate (conservative) significance tests (Littell et al. 1992).

The chemical composition of experimental feeds is presented in Table 1. The fermentation quality of silage was good. The $\mathrm{N}$ contents of all concentrate mixtures were very similar. The fat contents were higher in FA and GFA diets owing additional free fatty acids.

FA diets increased $(\mathrm{P}<0.001)$ milk yield despite reduced silage DM intake $(\mathrm{P}<0.01)$ (Table 2). However, total DM intake and ME intake were similar in all diets. FA supplementation 
Vol. 6 (1997): 349-362.

Table 1. Chemical composition of experimental feeds.

\begin{tabular}{lccccc}
\hline & Silage $^{1}$ & $\mathrm{CM}^{2}$ & $\mathrm{CM}+\mathrm{G}$ & $\mathrm{CM}+\mathrm{FA}$ & $\mathrm{CM}+\mathrm{GFA}$ \\
\hline Dry Matter $\left(\mathrm{g} \mathrm{kg}^{-1}\right)$ & 288 & 885 & 888 & 891 & 895 \\
In dry matter $\left(\mathrm{g} \mathrm{kg}^{-1}\right)$ & & & & & \\
$\mathrm{OM}$ & 913 & 930 & 927 & 927 & 928 \\
$\mathrm{~N}$ & 29.0 & 25.8 & 25.7 & 25.6 & 25.9 \\
$\mathrm{Hcl}$ fat & 58.2 & 38.1 & 36.3 & 65.3 & 68.3 \\
$\mathrm{NDF}$ & 560 & 236 & 219 & 228 & 215 \\
$\mathrm{ADF}$ & 309 & 88.6 & 77.9 & 80.1 & 78.7 \\
Lignin & 34.7 & 16.2 & 14.5 & 16.9 & 14.2 \\
Cellulose & 275 & 72.4 & 63.4 & 63.2 & 64.5 \\
Hemicellulose & 250 & 148 & 141 & 148 & 136 \\
\hline
\end{tabular}

' In silage: $\mathrm{pH} 4.26$; in DM ( $\mathrm{g} \mathrm{kg}^{-1}$ ): water-soluble carbohydrates 48.6; lactic acid 66.3; acetic acid 18.8; propionic acid 0.08 ; butyric acid 0.47 ; isovaleric acid 0.028 ; ethanol 2.6 ; in total $\mathrm{N}\left(\mathrm{g} \mathrm{kg}^{-1}\right)$ : ammonia N 58.6; soluble N 479. Cellulose digestibility of silage DM 0.752. Cellulose=ADF-lignin, Hemicellulose $=\mathrm{NDF}-\mathrm{ADF}$.

${ }^{2} \mathrm{CM}=$ concentrate mixture, $\mathrm{CM}+\mathrm{G}=$ concentrate mixture inluding glycerol, $\mathrm{CM}+\mathrm{FA}=$ concentrate mixture inluding unprotected free fatty acids, $\mathrm{CM}+\mathrm{GFA}=$ concentrate mixture inluding both glycerol and unprotected free fatty acids. $\mathrm{G}=$ glycerol; $\mathrm{FA}=$ free fatty acids; $\mathrm{GFA}=$ glycerol and free fatty acids; OM=organic matter; $\mathrm{NDF}=$ neutral detergent fibre; $\mathrm{ADF}=$ acid detergent fibre

Table 2. Effect of various supplements on feed intake, milk yield, milk composition, yield of milk constituents and live weight.

\begin{tabular}{|c|c|c|c|c|c|c|c|c|}
\hline & \multicolumn{4}{|c|}{ Treatment } & \multirow[b]{2}{*}{ SEM } & \multicolumn{3}{|c|}{ Significance of effect } \\
\hline & $\mathrm{C}$ & G & FA & GFA & & G & FA & GxFA \\
\hline \multicolumn{9}{|c|}{ Feed intake $\left(\mathrm{kg} \mathrm{DM}\right.$ day $\left.^{-1}\right)$} \\
\hline Silage & 10.18 & 10.06 & 9.94 & 9.74 & 0.108 & NS & ** & NS \\
\hline Supplement & 6.09 & 6.01 & 6.11 & 6.15 & 0.058 & & & \\
\hline Total intake & 16.27 & 16.06 & 16.05 & 15.89 & 0.115 & NS & NS & NS \\
\hline Silage+suppl. g/W 0.75 & 148 & 146 & 147 & 146 & 1.1 & NS & NS & NS \\
\hline ME intake $(\mathrm{MJ})$ & 187 & 185 & 189 & 188 & 1.3 & NS & NS & NS \\
\hline $\mathrm{ECM}^{1}$ yield $\left(\mathrm{kg} \mathrm{day}^{-1}\right)$ & 22.52 & 22.08 & 23.07 & 23.19 & 0.206 & NS & $* * *$ & NS \\
\hline Milk yield $\left(\mathrm{kg} \mathrm{day}^{-1}\right)$ & 22.98 & 22.21 & 23.47 & 23.69 & 0.258 & NS & $* * *$ & $\mathrm{P}=0.07$ \\
\hline \multicolumn{9}{|c|}{ Milk composition ( $\left.\mathrm{g} \mathrm{kg}^{-1}\right)$} \\
\hline fat & 39.1 & 39.2 & 40.1 & 39.8 & 0.47 & NS & $\mathrm{P}=0.09$ & NS \\
\hline protein & 31.8 & 32.1 & 31.1 & 31.2 & 0.17 & NS & $* * *$ & NS \\
\hline lactose & 49.7 & 49.4 & 49.6 & 49.9 & 0.12 & NS & $\mathrm{P}=0.09$ & * \\
\hline \multicolumn{9}{|c|}{ Yield of milk constituents ( $\mathrm{g}$ day-1) } \\
\hline fat & 891 & 873 & 934 & 937 & 11.0 & NS & $* * *$ & NS \\
\hline protein & 726 & 714 & 727 & 740 & 8.0 & NS & $\mathrm{P}=0.10$ & NS \\
\hline lactose & 1148 & 1124 & 1170 & 1195 & 12.5 & NS & $* * *$ & $\mathrm{P}=0.06$ \\
\hline \multicolumn{9}{|l|}{ Live weight (kg) } \\
\hline mean & 527 & 527 & 522 & 523 & 1.6 & NS & ** & NS \\
\hline change $\left(\right.$ day $\left.^{-1}\right)$ & +0.424 & +0.408 & +0.325 & +0.143 & 0.1238 & NS & NS & NS \\
\hline
\end{tabular}

Statistical significance: NS, $\mathrm{P}>0.10$ not significant; ${ }^{*} \mathrm{P}<0.05 ;{ }^{* *} \mathrm{P}<0.01 ;{ }^{* * *} \mathrm{P}<0.001$

${ }^{1} \mathrm{ECM}=$ energy corrected milk (Sjaunja et al. 1990)

$\mathrm{C}=$ concentrate mixture $(\mathrm{CM}) ; \mathrm{G}=\mathrm{CM}+$ glycerol; $\mathrm{FA}=\mathrm{CM}+$ fatty acids; $\mathrm{GFA}=\mathrm{CM}+$ glycerol+fatty acids 


\section{AGRICULTURAL AND FOOD SCIENCE IN FINLAND}

Khalili, H. et al. Glycerol and unprotected free fatty acids in the diets of dairy cows

Table 3. Effect of various supplements on milk fatty acid composition ( $\mathrm{g} \mathrm{kg}^{-1}$ fat).

\begin{tabular}{|c|c|c|c|c|c|c|c|c|}
\hline & \multicolumn{4}{|c|}{ Treatment } & \multirow[b]{2}{*}{ SEM } & \multicolumn{3}{|c|}{ Significance of effect } \\
\hline & $\mathrm{C}$ & G & FA & GFA & & G & FA & GxFA \\
\hline $\mathrm{C}_{4}$ & 55.3 & 56.5 & 56.5 & 59.3 & 1.95 & NS & NS & NS \\
\hline $\mathrm{C}_{6}$ & 29.0 & 29.8 & 28.0 & 28.5 & 0.93 & NS & NS & NS \\
\hline $\mathrm{C}_{8}$ & 16.0 & 16.0 & 14.0 & 14.5 & 0.50 & NS & $* *$ & NS \\
\hline $\mathrm{C}_{10}^{8}$ & 36.0 & 36.3 & 30.0 & 30.8 & 1.04 & NS & $* * *$ & NS \\
\hline $\mathrm{C}_{12}$ & 41.3 & 43.0 & 35.5 & 35.5 & 0.89 & NS & $* * *$ & NS \\
\hline $\mathrm{C}_{14: 0}^{12}$ & 128.5 & 133.5 & 118.3 & 121.3 & 2.12 & NS & $* * *$ & NS \\
\hline $\mathrm{C}_{14.0}$ & 15.5 & 16.3 & 13.8 & 14.0 & 0.29 & NS & $* * *$ & NS \\
\hline Total $\mathrm{C}_{4}-\mathrm{C}_{14}$ & 321.5 & 331.3 & 296.0 & 303.8 & 6.59 & NS & ** & NS \\
\hline $\mathrm{C}_{1600}$ & 293.5 & 278.8 & 268.8 & 264.3 & 10.28 & NS & $\mathrm{P}=0.10$ & NS \\
\hline $\mathrm{C}_{16: 1}^{16: 0}$ & 26.0 & 27.8 & 24.8 & 26.0 & 0.61 & $*$ & $*$ & NS \\
\hline Total $\mathrm{C}_{16}$ & 319.5 & 306.5 & 293.5 & 290.3 & 9.80 & NS & $\mathrm{P}=0.07$ & NS \\
\hline $\mathrm{C}_{18.0}$ & 111.0 & 109.0 & 128.5 & 129.8 & 2.54 & NS & $* * *$ & NS \\
\hline$C_{18.1}^{18.0}$ & 218.0 & 222.0 & 252.3 & 246.8 & 4.70 & NS & $* * *$ & NS \\
\hline$C_{18.2}^{18.1}$ & 20.5 & 22.0 & 21.3 & 22.0 & 1.33 & NS & NS & NS \\
\hline$C_{18,3}^{18.2}$ & 7.5 & 6.8 & 6.5 & 6.3 & 0.20 & $*$ & $* *$ & NS \\
\hline $\mathrm{C}_{20.1}$ & 3.3 & 2.8 & 4.0 & 3.5 & 0.25 & $\mathrm{P}=0.09$ & * & NS \\
\hline Total $\mathrm{C}_{18}-\mathrm{C}_{20}$ & 360.3 & 362.5 & 412.5 & 408.3 & 6.61 & NS & $* * *$ & NS \\
\hline
\end{tabular}

Statistical significance: NS, $\mathrm{P}>0.10$ not significant; ${ }^{*} \mathrm{P}<0.05 ;{ }^{* *} \mathrm{P}<0.01 ;{ }^{* * *} \mathrm{P}<0.001$

$\mathrm{C}=$ concentrate mixture $(\mathrm{CM}) ; \mathrm{G}=\mathrm{CM}+$ glycerol; $\mathrm{FA}=\mathrm{CM}+$ fatty acids; $\mathrm{GFA}=\mathrm{CM}+$ glycerol+fatty acids

tended ( $\mathrm{P}=0.09)$ to increase milk fat content and increased $(\mathrm{P}<0.001)$ milk fat yield. Milk protein content decreased $(\mathrm{P}<0.001)$ but, due to the greater milk yield, protein yield tended $(\mathrm{P}=0.10)$ to increase in response to FA supplementation. Mean live weight was lower $(\mathrm{P}<0.01)$ with FA diets. Inclusion of glycerol alone did not significantly affect silage intake, milk production, milk composition or live weight. However, glycerol tended to decrease milk yield without supplemental fat $(-0.77 v+0.22 \mathrm{~kg} / \mathrm{d} ; \mathrm{P}=0.07)$ and to increase milk yield with supplemental fat. Lactose yield also tended to decrease without supplemental fat $(-24 v+25 \mathrm{~g} / \mathrm{d} ; \mathrm{P}=0.06)$ and to increase with supplemental fat.

FA diets increased the proportions of $\mathrm{C}_{18: 0}$, $\mathrm{C}_{18: 1}(\mathrm{P}<0.001)$ and $\mathrm{C}_{20: 1}(\mathrm{P}<0.05)$ long-chain fatty acids and simultaneously decreased the total proportions of short-chain fatty acids $\left(\mathrm{C}_{4}-\mathrm{C}_{14}\right)$ $(\mathrm{P}<0.01)$ and the proportion of the total medium-chain fatty acids $\mathrm{C}_{16}(\mathrm{P}=0.07)$ in milk fat
(Table 3). Due to the increased fat yield (Table 2) and proportions (Table 3) of $\mathrm{C}_{18: 0}$ and $\mathrm{C}_{18: 1}$, secretions of $\mathrm{C}_{18: 0}$ and $\mathrm{C}_{18: 1}$ increased significantly $(\mathrm{P}<0.001)(\mathrm{C} \operatorname{diet} 99.1$ and $194.9 v$ FA diet 120.2 and 235.7 for $\mathrm{C}_{18: 0}$ and $\mathrm{C}_{18: 1}$, respectively,) but secretions of total $\mathrm{C}_{4}-\mathrm{C}_{14}$ and total $\mathrm{C}_{16}$ remained unaltered (results not shown in Table 3). Glycerol supplementation increased $(\mathrm{P}<0.05)$ the proportion of $C_{16: 1}$ and decreased that of $C_{18: 3}$ (Table 3). No interaction affecting for the proportion or production of milk fatty acids was noticed between glycerol and free fatty acids.

FA diets increased $(\mathrm{P}<0.001)$ the mean value of the three sampling times of plasma NEFA concentration (Table 4). There was an interaction between glycerol and free fatty acids in the mean value of the plasma urea concentration, resulting in a decrease $(\mathrm{P}<0.05)$ in urea concentration when FA was included in the diet with glycerol. Postprandial values of BHB and urea were highest and those of glucose and NEFA 
Vol. 6 (1997): 349-362.

Table 4. Effect of various supplements on the concentrations $\left(\mathrm{mmol} \mathrm{1}^{-1}\right)$ of some blood and plasma metabolites.'

\begin{tabular}{|c|c|c|c|c|c|c|c|c|}
\hline & \multicolumn{4}{|c|}{ Treatment } & \multirow[b]{2}{*}{ SEM } & \multicolumn{3}{|c|}{ Significance of effect } \\
\hline & $\mathrm{C}$ & G & FA & GFA & & G & FA & GxFA \\
\hline $\mathrm{BHB}^{2}\left(\mathrm{mmol} \mathrm{l}^{-1}\right)$ & 0.58 & 0.58 & 0.58 & 0.58 & 0.017 & NS & NS & NS \\
\hline Glucose $\left(\mathrm{mmol} \mathrm{I}^{-1}\right)$ & 3.35 & 3.28 & 3.33 & 3.36 & 0.041 & NS & NS & NS \\
\hline Urea $\left(\mathrm{mmol} \mathrm{I}^{-1}\right)$ & 4.87 & 4.88 & 5.14 & 4.76 & 0.083 & * & NS & $*$ \\
\hline $\mathrm{NEFA}^{3}\left(\mathrm{mmol} \mathrm{I}^{-1}\right)$ & 0.096 & 0.096 & 0.133 & 0.119 & 0.0052 & NS & **** & NS \\
\hline
\end{tabular}

Statistical significance: NS, $\mathrm{P}>0.10$ not significant; ${ }^{*} \mathrm{P}<0.05 ;{ }^{* *} \mathrm{P}<0.01 ;{ }^{* * *} \mathrm{P}<0.001$

${ }^{1}$ Means of three sampling times. ${ }^{2} \mathrm{BHB}=$ Beta-hydroxybutyrate. ${ }^{3} \mathrm{NEFA}=$ nonesterified fatty acids.

$\mathrm{C}=$ concentrate mixture $(\mathrm{CM}) ; \mathrm{G}=\mathrm{CM}+$ glycerol; $\mathrm{FA}=\mathrm{CM}+$ fatty acids; $\mathrm{GFA}=\mathrm{CM}+$ glycerol+fatty acids

Table 5. Effect of various supplements on digestibilities of dry matter (DM), organic matter (OM), (N), fat and neutral detergent fibre (NDF) (four ruminally cannulated cows).

\begin{tabular}{|c|c|c|c|c|c|c|c|c|}
\hline & \multicolumn{4}{|c|}{ Treatment } & \multirow[b]{2}{*}{ SEM } & \multicolumn{3}{|c|}{ Significance of effect } \\
\hline & $\mathrm{C}$ & G & FA & GFA & & G & FA & GxFA \\
\hline DM & 0.759 & 0.752 & 0.744 & 0.747 & 0.0029 & NS & $* *$ & NS \\
\hline OM & 0.776 & 0.768 & 0.760 & 0.762 & 0.0032 & NS & $* *$ & NS \\
\hline $\mathrm{N}$ & 0.726 & 0.723 & 0.713 & 0.718 & 0.0045 & NS & $\mathrm{P}=0.09$ & NS \\
\hline FAT & 0.625 & 0.618 & 0.648 & 0.669 & 0.0041 & NS & $* * *$ & ** \\
\hline NDF & 0.734 & 0.719 & 0.715 & 0.705 & 0.0070 & NS & * & NS \\
\hline
\end{tabular}

Statistical significance: NS, $\mathrm{P}>0.10$ not significant; ${ }^{*} \mathrm{P}<0.05 ;{ }^{* *} \mathrm{P}<0.01 ;{ }^{* * *} \mathrm{P}<0.001$

$\mathrm{C}=$ concentrate mixture $(\mathrm{CM}) ; \mathrm{G}=\mathrm{CM}+$ glycerol; $\mathrm{FA}=\mathrm{CM}+$ fatty acids; $\mathrm{GFA}=\mathrm{CM}+$ glycerol+fatty acids

lowest $3 \mathrm{~h}$ after morning feeding compared with the values before feeding and $6 \mathrm{~h}$ after feeding with each diet (results not shows here).

FA diets decreased $(\mathrm{P}<0.01)$ digestibilities of $\mathrm{DM}, \mathrm{OM}$ and $(\mathrm{P}<0.05) \mathrm{NDF}$ and tended to decrease the digestibility of $\mathrm{N}(\mathrm{P}=0.09)$ but increase $(\mathrm{P}<0.001)$ that of ether extract fat (Table 5). Glycerol inclusion had no significant effect on digestibility. An interaction $(\mathrm{P}<0.01)$ affecting fat digestibility was observed between glycerol and FA .

FA diets did not significantly affect the average (seven sampling times) rumen fermentation parameters or numbers of protozoa (Table 6). In contrast, $\mathrm{G}$ diets altered the rumen fermentation type, the molar proportion of acetate decreasing $(\mathrm{P}<0.001)$ and the proportions of propionate, butyrate and valerate increasing $(\mathrm{P}<0.05$ at least $)$. Glycerol decreased $(\mathrm{P}<0.05)$ the number of Holotrich protozoa. There were no effects of an interaction between glycerol and fatty acids on rumen fermentation parameters or protozoal numbers.

Postprandial changes in molar proportions of acetate, propionate and butyrate are shown in Figure 1a-c. G diets caused interactions with time for acetate and butyrate, decreasing $\left(\mathrm{G}^{*} \mathrm{~h}\right.$ $\mathrm{P}<0.01)$ the postprandial value of acetate and increasing $\left(\mathrm{G}^{*} \mathrm{~h} \mathrm{P}<0.001\right)$ that of butyrate. 


\section{AGRICULTURAL AND FOOD SCIENCE IN FINLAND}

Khalili, H. et al. Glycerol and unprotected free fatty acids in the diets of dairy cows

Table 6. Effect of various supplements on rumen fermentation characteristics' (four ruminally cannulated cows, mean values of seven sampling times).

\begin{tabular}{|c|c|c|c|c|c|c|c|c|}
\hline & \multicolumn{4}{|c|}{ Treatment } & \multirow[b]{2}{*}{ SEM } & \multicolumn{3}{|c|}{ Significance of effect } \\
\hline & $\mathrm{C}$ & G & FA & GFA & & G & FA & GxFA \\
\hline $\mathrm{pH}$ & 6.27 & 6.29 & 6.28 & 6.37 & 0.058 & NS & NS & NS \\
\hline $\mathrm{NH}_{4}-\mathrm{N}\left(\mathrm{mmol} \mathrm{I}^{-1}\right)$ & 10.45 & 9.02 & 9.48 & 9.35 & 0.638 & NS & NS & NS \\
\hline Total VFA $\left(\mathrm{mmol} \mathrm{l}^{-1}\right)$ & 120.6 & 122.4 & 120.6 & 120.4 & 1.74 & NS & NS & NS \\
\hline \multicolumn{9}{|c|}{ Molar proportion of VFA's (mmol mol-1) } \\
\hline Acetate & 656 & 637 & 655 & 637 & 2.9 & *** & NS & NS \\
\hline Propionate & 170 & 176 & 172 & 178 & 2.3 & * & NS & NS \\
\hline Isobutyrate & 9.5 & 9.4 & 8.9 & 9.8 & 0.28 & NS & NS & NS \\
\hline Butyrate & 133 & 144 & 134 & 142 & 1.3 & * & NS & NS \\
\hline Isovalerate & 12.5 & 12.5 & 11.9 & 13.1 & 0.40 & NS & NS & NS \\
\hline valerate & 13.9 & 15.4 & 13.6 & 14.8 & 0.40 & ** & NS & NS \\
\hline Caproate & 6.3 & 6.5 & 6.6 & 6.5 & 0.25 & NS & NS & NS \\
\hline \multicolumn{9}{|l|}{ Protozoa $\left(\times 10^{4} \mathrm{ml}^{-1}\right)$} \\
\hline Total & 19.1 & 19.2 & 18.3 & 17.5 & 1.00 & NS & NS & NS \\
\hline Holotricha & 1.4 & 1.0 & 1.8 & 1.2 & 0.20 & * & NS & NS \\
\hline Entodiniomorph & 17.7 & 18.2 & 16.5 & 16.3 & 1.17 & NS & NS & NS \\
\hline
\end{tabular}

Statistical significance: NS, $\mathrm{P}>0.10$ not significant; ${ }^{*} \mathrm{P}<0.05 ;{ }^{* *} \mathrm{P}<0.01 ;{ }^{* * *} \mathrm{P}<0.001$

' Means of seven sampling times

$\mathrm{C}=$ concentrate mixture $(\mathrm{CM}) ; \mathrm{G}=\mathrm{CM}+$ glycerol; $\mathrm{FA}=\mathrm{CM}+$ fatty acids; $\mathrm{GFA}=\mathrm{CM}+$ glycerol+fatty acids

\section{Discussion}

\section{Effects of free fatty acids}

Inclusion of unprotected supplementary fats has had both beneficial and adverse effects on dairy cow feeding and production, depending on factors such as the amount and type of fat given. The mixture of unprotected free fatty acids used in the present trial consisted mainly of $\mathrm{C}_{18: 1}$ ( 376 $\mathrm{g} / \mathrm{kg})$ and $\mathrm{C}_{18: 2}(274 \mathrm{~g} / \mathrm{kg})$ fatty acids. The effects of supplementary fats with very different fatty acid compositions are not therefore referred to in this paper.

\section{Feed intake, milk production and composition}

Replacement of barley by $36 \mathrm{~g} / \mathrm{kg}$ of a mixture of free fatty acids decreased silage DM intake in the cows given FA diets. Generally, high concentrations of supplementary fat have decreased feed DM intake but the results of many trials with supplementary fat have been less consistent (Coppock and Wilks 1991). FA supplementation increased milk yield in the trial discussed here. Such an increase has often been observed if the effect on feed intake has been slight or non-negative, resulting in increased energy intake. The estimated ME intake did not increase significantly with FA diets and there were no differences in ME balances (intake-requirement). As shown by Coppock and Wilks (1991), FA diets tended to increase milk fat content and decrease milk protein content. A decrease in milk protein content has often, but not invariably, been reported and the reasons for such a decrease are not clear. It is not easy to explain the decrease in milk protein here either, because there were no changes in the concentrations of plasma glucose or rumen ammonia. Furthermore, the amino acid supply from the small intestine was estimated to be higher than that recommended (maintenance and milk production, ignoring live weight change) 
Vol. 6 (1997): 349-362.
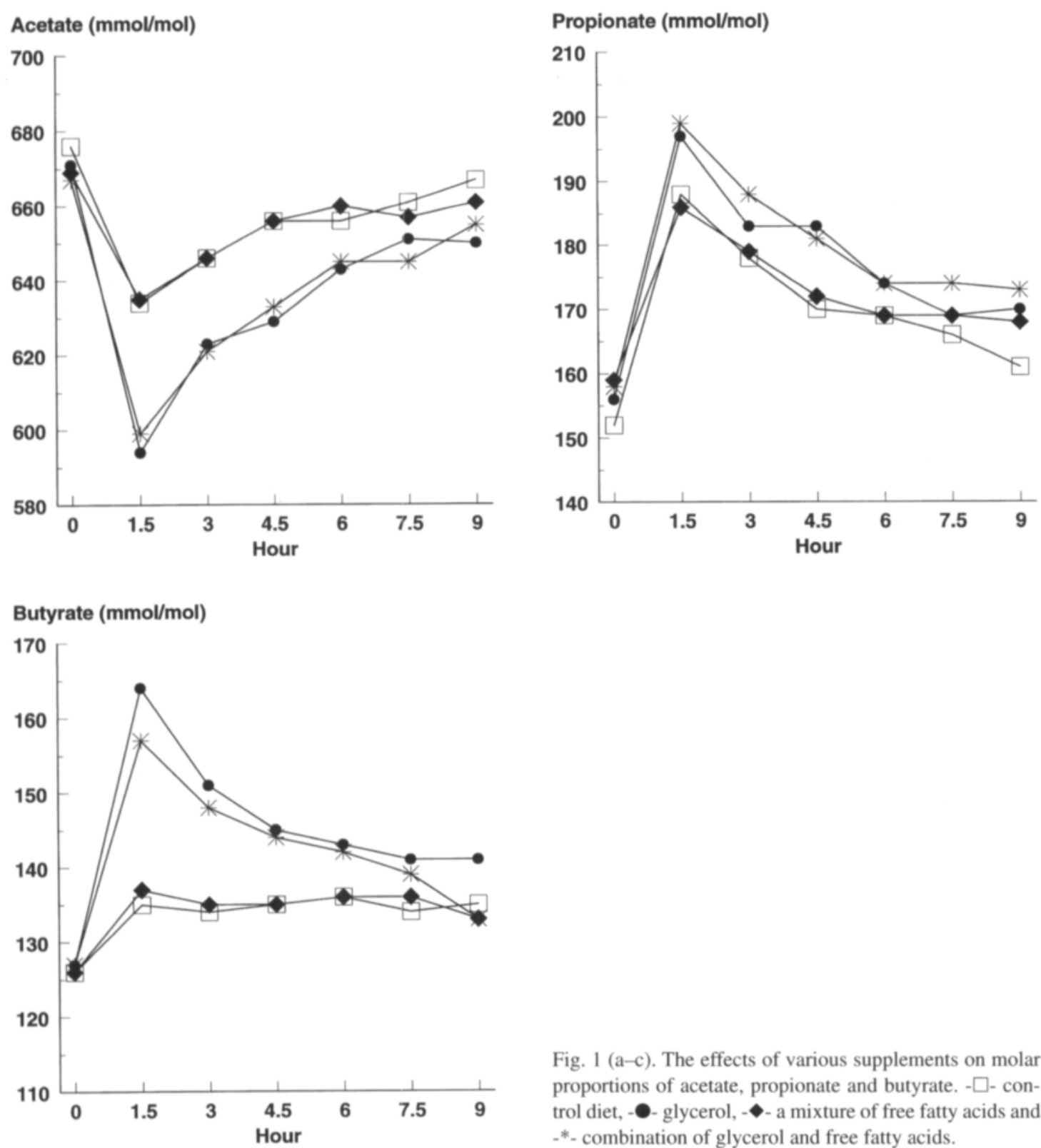

Fig. $1(\mathrm{a}-\mathrm{c})$. The effects of various supplements on molar proportions of acetate, propionate and butyrate. - $\square$ - control diet, - - glycerol, - - a mixture of free fatty acids and -*- combination of glycerol and free fatty acids.

(Madsen et al. 1995) in each diet. The main cause of the decrease in milk protein content here was the dilution effect due to increased milk yield. Wu and Huber (1994) attribute the decrease in milk protein concentration associated with supplemental fat partly to increased milk yield.

\section{Milk fatty acids}

It is well documented that dietary fats affect milk FA composition (Palmquist and Jenkins 1980). In the present trial, free FA in FA diets modified milk FA composition by increasing long-chain 


\section{AGRICULTURAL AND FOOD SCIENCE IN FINLAND}

Khalili, H. et al. Glycerol and unprotected free fatty acids in the diets of dairy cows

FA derived from the diet. However, because the dietary supply of free fatty acids (main components in the FA mixture were $\mathrm{C}_{18: 1}$ and $\mathrm{C}_{18: 2}$ ) is modified within the rumen, the long-chain FA profile of milk changed, increasing the proportions of $\mathrm{C}_{18: 0}$ and $\mathrm{C}_{18: 1}$. Unsaturated free fatty acids are rapidly hydrogenated by rumen $\mathrm{mi}$ crobes into more saturated fatty acids at rates depending on factors such as the nature and amount of lipids fed (Jenkins 1993). According to Doreau and Ferlay (1994), the higher the linoleic acid concentration in the diet the greater is the extent of hydrogenation of linoleic acid. Judging by the lack of an increase in the linoleic acid in milk despite the addition of linoleic acid, this is most probably what occurred here. The hydrogenation of linoleic acid $\left(\mathrm{C}_{18: 2 \mathrm{n}-6}\right)$ is not complete, but provides stearic acid and different isomers of $\mathrm{C}_{18: 1}$ (Tamminga and Doreau 1991). This hydrogenation was also indicated here by the increase in $\mathrm{C}_{18: 0}$ and $\mathrm{C}_{18: 1}$ with $\mathrm{FA}$ diets. A supply of dietary fatty acids in FA diets could have reduced de novo synthesis of $\mathrm{C}_{18: 0}$ and $\mathrm{C}_{16: 0}$ fatty acids by rumen bacteria (Jenkins 1993) probably because of enhanced uptake of exogenous lipids by bacteria (Poncet et al. 1995). Furthermore, a decrease in the content of $\mathrm{C}_{16}$ in milk with FA diets was affected by the supply of $\mathrm{C}_{18}$ fatty acids and their subsequent uptake by the mammary gland, which inhibits de novo synthesis of short- chain fatty acids (Palmquist and Jenkins 1980).

FA diets increased the intake of free fatty acids by about $170 \mathrm{~g} / \mathrm{d}$, which increased the production of $\mathrm{C}_{18}$ fatty acids by $62.9 \mathrm{~g} / \mathrm{d}$ in milk and simultaneously slightly decreased de novo synthesis of short-chain fatty acids in the mammary cell. Doreau and Ferlay (1994) concluded that it is currently difficult to predict the amount of absorbable FA, since the factors controlling the synthesis and disappearance of FA in the rumen are not well known.

\section{Blood metabolites}

FA diets did not affect the blood BHB concentration, a finding supporting the conclusion that BHB concentrations do not usually markedly increase during fat supplementation (Grummer and Carroll 1991). As found in fat studies (Dhiman et al. 1995, Choi and Palmquist 1996), FA diets did not have any effect on the glucose concentration in plasma. According to Grummer and Carroll (1991), it seems likely that fat supplementation spares glucose from oxidation, but that the metabolic consequences are unknown. They concluded that fat supplementation does not consistently increase blood glucose. The plasma NEFA concentrations of lactating cows fed supplemental fat almost invariably increase (Grummer and Carroll 1991). In the present trial too, FA diets increased the NEFA concentration, which did not indicate increased lipolysis since the cows were in mid-lactation and their energy balance was positive, as shown by the positive live weight change and energy balance. An increased plasma NEFA concentration was probably related to an increased dietary supply of additional free fatty acids rather than to net changes in the balance between lipolysis and lipogenesis.

\section{Digestibility}

FA inclusion has been shown to reduce digestibilities of OM and fibre (Palmquist and Jenkins 1980, Tesfa 1992, Jenkins 1993), as was also observed in the present trial with FA diets. However, free fatty acids reduced the digestibilities of OM and NDF in FA diets only slightly, partly due to the high proportion of $\mathrm{C}_{18: 1}$ in the mixture of FA used and to the total amount of FA given. Note that the mixture of free FA included polyunsaturated FA. According to Chalupa et al. (1984), lipids rich in short-chain, medium-chain or poly-unsaturated fatty acids have a greater negative effect on carbohydrate, especially fibre, digestion than have saturated or mono-unsaturated long-chain fatty acids. Here, a slight depression in NDF digestibility might be one reason for the observed decrease in feed intake. Although several mechanisms may be operative in the rumen to explain the reduction in fibre digestion when fatty acids are given, Palmquist and Jenkins (1980) concluded that most data suggest an inhibitory effect on microbial activi- 
Vol. 6 (1997): 349-362.

ty. When fibre digestibility has been depressed by lipids, the fermentation type, too, has often been modified through an increased proportion of propionate in the rumen. This is probable due to a decrease in the activity of cellulolytic bacteria. According to a recent review by Doreau and Ferlay (1995), lipid supplements decrease the protozoal counts in the rumen but this effect is very variable. They also noted that the negative effect on protozoa seems to be more marked with free than with esterified fatty acids and that the strongest decrease in protozoal number has been associated with a significant drop in the ammonia concentration in the rumen. Including a low level of free FA in a silage-based diet did not affect the rumen ammonia concentration or the protozoal number in FA diets. In the present trial, FA supplementation did not affect the rumen fermentation pattern, which is consistent with no change in protozoal numbers. In contrast, Tesfa (1992) reported a decrease in protozoal number, an increase in the proportion of propionate and a decrease in that of butyrate in the rumen in response to a daily supplement of $0.5 \mathrm{~kg}$ rapeseed oil.

\section{Effects of glycerol}

In the present trial, inclusion of glycerol did not affect feed intake or milk yield and had only a slight effect on milk fatty acid composition and plasma urea concentration. Few papers have been published on the effects of glycerol as an energy yielding substrate in dairy cow feeding. Remond et al. (1991) reported no effects on milk yield, milk composition or food intake when glycerol was given in amounts to those in the present trial.

The ability to increase the proportion of propionate in the rumen at the expense of other volatile fatty acids by using glycerol was investigated in the present trial with grass silage-based diets. The effects of glycerol on rumen fermentation reported elsewhere have varied due to differences in diets; and the effects have not been studied using grass silage-based diets. Wright (1969) observed increases in acetic and propi- onic acids but Remond et al. (1993) reported that glycerol increased butyrate more than it did propionate at the expense of acetate, as was noticed here, too. Glycerol did not affect either blood glucose or BHB concentrations, but Remond et al. (1991) observed that glycerol increased the plasma 3-hydroxybutyrate concentration. In the present trial the increase in butyrate was not due to the $\mathrm{pH}$ effect since the mean value of rumen $\mathrm{pH}$ was not affected with $\mathrm{G}$ diets. It is not easy to explain why butyrate increased more than did propionate with glycerol supplementation. It is possible, however that propionate formation depressed when fermentation proceeds rapidly in the rumen. Our results with grass silage-based diets confirmed the observations of Remond et al. (1993) that an increase in butyrate is not evidence of the glucogenic ability of glycerol in dairy cows given maize silage. According to Broster et al. (1970), both glucose and sucrose depressed the proportion of acetate and increased the proportions of propionate and butyrate when a basal diet of hay and concentrates was supplemented with glucose or sucrose in dairy cow feeding. They reported that glucose diets increased butyrate more than sucrose. Similarly, when cattle were fed purified diets, glucose diets increased the proportion of butyrate more than that of propionate (Ørskov and Oltjen 1967). Glucose and sucrose supplements tended to increase the proportion of propionate and butyrate. However, these changes were not statistically significant in goats given a silage diet (Chamberlain et al. 1985).

\section{Conclusions}

The low level of fatty acids used only slightly decreased silage intake and diet OM digestibility. Fatty acids did not change the rumen fermentation type or the ammonia concentration or protozoal numbers in the rumen. On the other hand, fatty acids increased the milk yield and simultaneously decreased the milk protein content but 
Khalili, H. et al. Glycerol and unprotected free fatty acids in the diets of dairy cows

not the protein yield. Furthermore, milk composition changed and the proportions of $\mathrm{C}_{18: 0}$ and $\mathrm{C}_{18: 1}$ fatty acids in milk fat increased.

Our findings suggest that the addition of glycerol to the diet does not have any positive ef- fects when cows are fed grass silage-based diets. However, when glycerol and fatty acids are given in combination there tended to be a positive effect on milk production.

\section{References}

Anttila, V. \& Kankare, V. 1983. The fatty acid composition of milk lipids. Milchwissenschaft 38: 478-481.

AOAC. 1990. Official methods of analysis. Fat (crude) or ether extract in animal feed (920.39). Association of Official Analytical Chemists. $15^{\text {th }}$ Edition.

Bergman, E.N. \& Pell, J.M. 1985. Intergration of amino acid metabolism in the ruminant. In: Gilchrist, F.M.C. \& Mackie, R.J. (eds.). Herbivore nutrition in the subtropics and tropics. Johannesburg: The Science Press. p. 613-628.

Broster, W.H., Sutton, J.D., Smith, T., Broster, V.J. \& Balch, C.C. 1970. The effect of supplements of sucrose and of glucose monohydrate on the milk production and live weight of dairy cows. Journal of Agricultural Science Cambridge 74: 217-225.

Chalupa, W., Rickabaugh, B., Kronfeld, D.S. \& Sklan, D. 1984. Rumen fermentation in vitro as influenced by long-chain fatty acids. Journal of Dairy Science 67: 1439-1444.

Chamberlain, D.G., Thomas, P.C., Wilson, W., Newbold, C.J. \& MacDonald, J.C. 1985. The effects of carbohydrate supplements on ruminal concentrations of ammonia in animals given diets of grass silage. Journal of Agricultural Science Cambridge 104: 331-340.

Choi, B.R. \& Palmquist, D.L. 1996. High fat diets increase plasma cholecystokinin and pancreatic polypeptide, and decrease plasma insulin and feed intake in lactating cows. Journal of Nutrition 126: 2913-2919.

Coppock, C.E. \& Wilks, D.L. 1991. Supplemental fat in high-energy rations for lactating cows: effects on intake, digestion, milk yield, and composition. Journal of Animal Science 69: 3826-3837.

Dhiman, T.R., Klaas, V.Z. \& Satter, L.D. 1995. Effect of dietary fat source on fatty acid composition of cow's milk. Journal of the Science of Food and Agriculture 69: 101-107.

Doreau, M. \& Ferlay, A. 1994. Digestion and utilisation of fatty acids by ruminants. Animal Feed Science and Technology 45: 379-396.

- \& Ferlay, A. 1995. Effect of dietary lipids on nitrogen metabolism in the rumen: a review. Livestock Production Science 43: 97-110.

Grummer, R.R. \& Carroll, D.J. 1991. Effects of dietary fat on metabolic disorders and reproductive performance of dairy cattle. Journal of Animal Science 69: 3838-3852.

Gutmann, I. \& Bergmeyer, H.U. 1974. Determination of urea with glutamate dehydrogenase as indicator en- zyme. In: Bergmeyer, H.U. (eds.). Methods of enzymatic analysis. 2nd English ed. Vol 4. Academic Press, New York. p. 1794-1798.

Huhtanen, P. 1988. The effects of supplementation of silage diet with barley, unmolassed sugar beet pulp and molasses on organic matter, nitrogen and fibre digestion in the rumen of cattle. Animal Feed Science and Technology 20: 259-278.

Huida, L., Väătäinen, H. \& Lampila, M. 1986. Comparison of dry matter contents in grass silage as determined by oven drying and gas chromatographic water analyses. Annales Agriculturae Fenniae 25: 215230.

Jaakkola, S. \& Huhtanen, P. 1993. The effects of the forage preservation method and the proportion of concentrate on nitrogen digestion and rumen fermentation in cattle. Grass and Forage Science 48: 155165.

Jenkins, T.C. 1993. Lipid metabolism in the rumen. Journal of Dairy Science 76: 3851-3863.

Littell, R.C., Freund, R.J. \& Spector, P.C. 1992. SAS System for Linear Models. SAS series in statictical applications. Third Edition. 329 p.

Madsen, J., Hvelplund, T., Weisbjerg, M.R., Bertilsson, J., Olsson, I., Spörndly, R., Harstad, O.M., Volden, H., Tuori, M., Varvikko, T., Huhtanen, P. \& Olafsson, B.L. 1995. The AAT/PBV protein evaluation system for ruminants. A revision. Norwegian Journal of Agricultural Sciences Supplement No. 19. p. 37.

McCullough, H. 1967. The determination of ammonia in whole blood by a direct colorimetric method. Clinical Chimica Acta 17: 297-304.

Ørskov, E.R. \& Oltjen, R.R. 1967. Influence of carbohydrate and nitrogen sources on the rumen volatile fatty acids and ethanol of cattle fed purified diets. Journal of Nutrition 93: 222-228.

Palmquist, D.L. \& Jenkins, T.C. 1980. Fat in lactation rations: review. Journal of Dairy Science 63: 1-14.

Poncet, C., Michalet-Doreau, B., McAllister, T. \& Remond, D. 1995. Dietary components escaping rumen digestion. In: Journet, M. et al. (eds.). Recent development in the nutrition of herbivores. Proceedings of the IVth International Symposium on the Nutrition of Herbivores. INRA Editions, Paris. p. 167-204.

Remond, B., Rouel, J. \& Ollier, A. 1991. Effet de l'addition de glycerol a la ration des vaches laitieres sur leur production et sur quelques parametres de leur metabolisme. Annales de Zootechnie 40: 59-66. 


\section{AGRICULTURAL AND FOOD SCIENCE IN FINLAND}

Vol. 6 (1997): 349-362.

- , Souday, E. \& Jouany, J.P. 1993. In vitro and in vivo fermentation of glycerol by rumen microbes. Animal Feed Science and Technology 41: 121-132.

Robertson, J.B. \& Van Soest, P.J. 1981. The detergent system of analysis and its application to human foods. In: James, W.D.T. \& Theander, O. (eds.). The analyses of dietary fibre in foods. New York, NY, Marcell Dekker, p. 123-158.

Shimizu, S., Tani, Y., Yamada, H., Tabata, M. \& Murachi, T. 1980. Enzymatic determination of serum free fatty acids: a colorimetric method. Analytical Biochemistry 107: 193-198.

Sjaunja, L.O., Baevre, L., Junkkarinen, L., Pedersen, J. \& Setälä, J. 1990. A Nordic proposal for an energy corrected milk (ECM) formula. In: 27th Session International Committee of Recording and Productivity of Milk Animal. Paris, France p. 156-157.

Tamminga, S. \& Doreau, M. 1991. Lipids and rumen digestion. In: Jouany, J.P. (ed.). Rumen microbial metabolism and ruminant digestion. INRA editions, Paris. p. 151-163.

Tesfa, A.T. 1992. Rapeseed oil in ruminants diet: its effect on rumen metabolism and animal performance. Academic Dissertation. Department of Animal Science, University of Helsinki, Finland. p. 53.

- , Syrjälă-Qvist, L. \& Tuori, M. 1991a. Replacement of grain by tallow or rapeseed oil in the diet of lactating cows and its effects on milk yield and composition. Finnish Journal of Dairy Science 49: 54-64.

- , Tuori, M. \& Syrjälă-Qvist, L. 1991b. High rapeseed oil feeding to lactating cows and its effects on milk yield and composition. Finnish Journal of Dairy Science 49: 65-81.

Thomas, P.C. \& Chamberlain, D.G. 1984. Manipulation of milk composition to meet market needs. In: Haresign, W. \& Cole, D.J.A. (eds.). Recent advances in animal nutrition. London: Butterworths. p. 219-243.

Työppönen, J. \& Kauppinen, K. 1980. The stability and automatic determination of ketone bodies in blood samples taken in field conditions. Acta Veterinaria Scandinavica 21: 55-61.

Van Keulen, J. \& Young, B.A. 1977. Acid insoluble ash as a natural marker for digestibility studies. Journal of Animal Science 44: 282-287.

Van Soest, P.J. 1994. Nutritional ecology of the ruminant. $2^{\text {nd }}$ ed. USA: Cornell University Press. $317 \mathrm{p}$.

Wright, D.E. 1969. Fermentation of glycerol by rumen micro-organisms. New Zealand Journal of Agricultural Research 12: 281-286.

Wu, Z. \& Huber, J.T.1994. Relationship between dietary fat supplementation and milk protein concentration in lactating cows: A review. Livestock Production Science 39: 141-155, 
Khalili, H. et al. Glycerol and unprotected free fatty acids in the diets of dairy cows

\title{
SELOSTUS
}

\section{Väkirehuun lisätyn glyserolin tai vapaiden rasvahappojen tai näiden yhdistelmän vaikutus maidontuotantoon ja pötsifermentaatioon ruokittaessa lypsylehmiä säilörehuun perustuvalla ruokinnalla}

\author{
Hannele Khalili, Tuomo Varvikko, Vesa Toivonen, Kari Hissa ja Marjatta Suvitie \\ Maatalouden tutkimuskeskus ja Suomen Rehu Oy
}

Tutkimuksessa selvitettiin lypsylehmille annettavaan väkirehuun lisätyn glyserolin tai suojaamattomien vapaiden rasvahappojen tai näiden yhdistelmän vaikutuksia rehun syöntiin, maidontuotantoon, maidon koostumukseen, pötsifermentaatioon, veriarvoihin ja ruokinnan sulavuuteen. Koejärjestelyssä mukana olleita 12 friisiläislehmää ruokittiin säilörehuun perustuvalla ruokinnalla. Koeruokintoja oli neljä. Kontrolliruokinnassa lehmille annettiin säilörehua ja perusväkirehua. Säilörehua lehmät saivat vapaasti ja perusväkirehua 7 kiloa päivässä. Kilogrammassa perusväkirehua oli $600 \mathrm{~g}$ ohraa, $80 \mathrm{~g}$ kauraa, $150 \mathrm{~g}$ leikettä, $95 \mathrm{~g}$ soijarouhetta, $20 \mathrm{~g}$ melassia ja muita $55 \mathrm{~g}$. Kahdessa koeväkirehussa $36 \mathrm{~g} / \mathrm{kg}$ ohraa oli korvattu joko glyserolilla tai rasvahapposeoksella. Yhdessä koeväkirehussa $72 \mathrm{~g} / \mathrm{kg}$ ohraa oli korvattu glyserolin (36 $\mathrm{g} / \mathrm{kg})$ ja rasvahappojen $(36 \mathrm{~g} / \mathrm{kg})$ yhdistelmällä. Rasvahappolisä koostui palmitiini- $\mathrm{C}_{1600}(126 \mathrm{~g} / \mathrm{kg})$, steariini- $\mathrm{C}_{18: 0}(22 \mathrm{~g} / \mathrm{kg})$, öljy- $\mathrm{C}_{18: 1}(376 \mathrm{~g} / \mathrm{kg})$, linoli- $\mathrm{C}_{18: 2}$ $(274 \mathrm{~g} / \mathrm{kg})$, linoleenihaposta $\mathrm{C}_{18: 3}(32 \mathrm{~g} / \mathrm{kg})$ ja vapaita rasvahappoja triglyseridimuodossa $(170 \mathrm{~g} / \mathrm{kg})$.
Rasvahapot heikensivät ruokinnan sulavuutta ja säilörehun syöntiä. Rasvahapot eivät kuitenkaan muuttaneet pötsifermentaatiotyyppiä, pötsin ammoniakkipitoisuutta eikä alkueläinten lukumäärää pötsissä. Maitotuotos lisääntyi ja samalla maidon valkuaispitoisuus pieneni hieman, mutta valkuaistuotos ei vähentynyt. Maidon rasvahappokoostumus parani siten, että steariini- ja öljyhapon suhteelliset osuudet lisääntyivät.

Glyserolilisä muutti pötsifermentaatiotyyppiä vähentäen etikkahapon suhteellista osuutta ja lisäten propioni- ja voihapon osuuksia. Muutokset fermentaatiossa olivat kuitenkin niin pieniä, etteivät betahydroksivoihapon ja glukoosin pitoisuudet veressä, maidontuotanto eikä maidon koostumus muuttuneet. Tämän kokeen tulosten perusteella glyserolilisäyksestä ei ollut hyötyä ruokittaessa lypsylehmiä säilörehuun perustuvalla ruokinnalla. Kuitenkin on todettava, että maidontuotanto oli suurinta annettaessa glyserolia ja rasvahappoja yhdessä. 